\title{
Contributions to twentieth century total column ozone change from halocarbons, tropospheric ozone precursors, and climate change
}

Article

Published Version

Creative Commons: Attribution-Noncommercial-No Derivative Works 3.0

Open Access

Reader, M. C., Plummer, D. A., Scinocca, J. F. and Shepherd, T. G. (2013) Contributions to twentieth century total column ozone change from halocarbons, tropospheric ozone precursors, and climate change. Geophysical Research Letters, 40 (23). pp. 6276-6281. ISSN 0094-8276 doi: https://doi.org/10.1002/2013GL057776 Available at https://centaur.reading.ac.uk/35574/

It is advisable to refer to the publisher's version if you intend to cite from the work. See Guidance on citing.

To link to this article DOI: http://dx.doi.org/10.1002/2013GL057776

Publisher: American Geophysical Union

All outputs in CentAUR are protected by Intellectual Property Rights law, including copyright law. Copyright and IPR is retained by the creators or other copyright holders. Terms and conditions for use of this material are defined in the End User Agreement. 


\section{www.reading.ac.uk/centaur}

\section{CentAUR}

Central Archive at the University of Reading

Reading's research outputs online 


\title{
Contributions to twentieth century total column ozone change from halocarbons, tropospheric ozone precursors, and climate change
}

\author{
M. C. Reader, ${ }^{1}$ D. A. Plummer, ${ }^{2}$ J. F. Scinocca, ${ }^{2}$ and T. G. Shepherd ${ }^{3}$ \\ Received 23 August 2013; revised 1 November 2013; accepted 11 November 2013; published 3 December 2013.
}

[1] We investigate ozone changes from preindustrial times to the present using a chemistry-climate model. The influence of changes in physical climate, ozone-depleting substances, $\mathrm{N}_{2} \mathrm{O}$, and tropospheric ozone precursors is estimated using equilibrium simulations with these different factors set at either preindustrial or present-day values. When these effects are combined, the entire decrease in total column ozone from preindustrial to present day is very small $(-1.8 \mathrm{DU})$ in the global annual average, though with significant decreases in total column ozone over large parts of the Southern Hemisphere during austral spring and widespread increases in column ozone over the Northern Hemisphere during boreal summer. A significant contribution to the total ozone column change is the increase in lower stratospheric ozone associated with the increase in ozone precursors (5.9 DU). Also noteworthy is the near cancelation of the global average climate change effect on ozone (3.5 DU) by the increase in $\mathrm{N}_{2} \mathrm{O}$ ( -3.9 DU). Citation: Reader, M. C., D. A. Plummer, J. F. Scinocca, and T. G. Shepherd (2013), Contributions to twentieth century total column ozone change from halocarbons, tropospheric ozone precursors, and climate change, Geophys. Res. Lett., 40, 6276-6281, doi:10.1002/2013GL057776.

\section{Introduction}

[2] Ozone residing in the stratosphere accounts for the bulk $(\approx 90 \%)$ of ozone in the atmosphere and absorbs much of the biologically harmful ultraviolet (UV-B) solar radiation before it reaches the surface of the Earth. Ozone in the troposphere, accounting for the remainder of the atmospheric ozone, also absorbs UV radiation [Brühl and Crutzen, 1989] but has additional significant negative effects since exposure to ozone is harmful to vegetation and human health [Gregg et al., 2003; Jerret et al., 2009].

\footnotetext{
Additional supporting information may be found in the online version of this article.

${ }^{1}$ School of Earth and Ocean Sciences, University of Victoria, Victoria, British Columbia, Canada.

${ }^{2}$ Canadian Centre for Climate Modelling and Analysis, Environment Canada, Victoria, British Columbia, Canada.

${ }^{3}$ Department of Meteorology, University of Reading, Reading, UK.

Corresponding author: M. C. Reader, School of Earth and Ocean Sciences, University of Victoria, P.O. Box 3055, Victoria, BC V8W 3P6, Canada. (cathy.reader@ec.gc.ca)

(C)2013 The Authors. Geophysical Research Letters published by Wiley on behalf of The American Geophysical Union.

This is an open access article under the terms of the Creative Commons Attribution-NonCommercial-NoDerivs License, which permits use and distribution in any medium, provided the original work is properly cited, the use is non- commercial and no modifications or adaptations are made. 0094-8276/13/10.1002/2013GL057776
}

[3] Ozone observations before the 1970's are very sparse, but total column ozone has been observed to decrease by approximately $3.5 \%$ between the $1970 \mathrm{~s}$ and $1990 \mathrm{~s}$, driven largely by decreases in stratospheric ozone due to increasing concentrations of reactive chlorine and bromine derived from ozone-depleting substances (ODSs) [World Meteorological Organization (WMO), 2011]. Modeling studies of ozone in the troposphere show significant increases since preindustrial times, driven by increased anthropogenic emissions of hydrocarbons and oxides of nitrogen $\left(\mathrm{NO}_{\mathrm{x}}\right)$ that participate in the photochemical production of tropospheric ozone [e.g., Lamarque et al., 2005; Young et al., 2013] and suggest that much of this increase was before 1970 [Cionni et al., 2011]. The very few observations of tropospheric ozone before the 1970s also suggest large increases in ozone near the surface since the end of the nineteenth century [Volz and Kley, 1988; Marenco et al., 1994]. More extensive and reliable observations since the 1970s show a heterogeneous pattern, with strongly positive to near-zero or slightly negative trends in tropospheric ozone found for different regions and time periods [Parrish et al., 2012; Oltmans et al., 2013].

[4] While ODSs are the dominant forcing on stratospheric ozone over the last 40 years [WMO, 2011], changing $\mathrm{CH}_{4}$, $\mathrm{N}_{2} \mathrm{O}$, and $\mathrm{CO}_{2}$ are recognized as having had an influence on ozone in the stratosphere as well. Increasing concentrations of $\mathrm{CH}_{4}$ can result in increased production of ozone in the lower stratosphere during methane oxidation [Randeniya et al., 2002], while the increased water vapor resulting from methane oxidation can further alter ozone chemistry [Dvortsov and Solomon, 2001]. Changes in the concentration of $\mathrm{N}_{2} \mathrm{O}$, as the source gas for reactive nitrogen compounds in the stratosphere, also have impacts on ozone, predominately in the middle-to-upper stratosphere where $\mathrm{NO}_{\mathrm{x}}$ chemistry is important. Increased $\mathrm{CO}_{2}$ cools the stratosphere and modifies the circulation. Cooler stratospheric temperatures have an impact on ozone chemistry directly [Jonsson et al., 2004] and through modifications to the chemistry of $\mathrm{NO}_{\mathrm{x}}$ [Rosenfield and Douglass, 1998], while dynamical changes affect transport of ozone and other chemically active species and induce temperature-dependent effects as well [Shepherd, 2008].

[5] Given the disparate factors that have influenced stratospheric and tropospheric ozone between the preindustrial and present day, we use a comprehensive stratospherictropospheric chemistry-climate model (CCM) to quantify how these factors may have combined to influence ozone in the last century. A suite of equilibrium simulations has been performed with the major forcings set to informative combinations of preindustrial and present-day conditions. In the next section the model and simulations performed are briefly 
READER ET AL.: TWENTIETH CENTURY COLUMN OZONE CHANGE

described; section 3 shows the effects of climate change and various chemical forcings on the ozone distribution, and in section 4 these results are discussed in the context of other modeling studies.

\section{Model Description and Validation}

[6] The Canadian Middle Atmosphere Model (CMAM) T47L71 chemistry-climate model was run in a configuration with specified SSTs, sea ice, and greenhouse gases (GHGs). It includes standard stratospheric chemistry accounting for $\mathrm{Cl}_{\mathrm{y}}-\mathrm{Br}_{\mathrm{y}}-\mathrm{O}_{\mathrm{x}}-\mathrm{HO}_{\mathrm{x}}-\mathrm{NO}_{\mathrm{x}}$ catalytic cycles and polar stratospheric cloud (PSC) chemistry on stratospheric ternary solution (STS) and PSC-II particles. The same chemical mechanism is used in the troposphere where it implicitly reduces to $\mathrm{CH}_{4}-\mathrm{NO}_{x}$ chemistry.

[7] The CMAM has a long history of involvement in the Chemistry-Climate Model Validation (CCMVal) project [Eyring et al., 2005] and given that, the stratospheric components of the model have been extensively compared with observations and against other CCMs showing CMAM to perform on par with the best of the current generation of CCMs [SPARC CCMVal, 2010]. The extension of the chemistry into the troposphere has been a more recent addition to CMAM. Results from the CMAM version used here have been submitted to the Atmospheric Chemistry and Climate Model Intercomparison Project (ACCMIP) and were found to compare well against the observations and fall well within the distribution of participating models for present-day (PD) and preindustrial (PI) conditions [Young et al., 2013]. Plots comparing zonal mean monthly climatologies of simulated present-day total and tropospheric column ozone with TOMS/SBUV and OMI-MLS TCO satellite retrievals, respectively, are presented in the supporting information. While the CMAM does not account for the chemistry of non-methane volatile organic compounds (NMVOCs), model sensitivity studies [Shindell et al., 2009; Stevenson et al., 2013] attribute much of the increase in tropospheric ozone since 1850 to the increase in methane and $\mathrm{NO}_{\mathrm{x}}$, with only a minor contribution from NMVOCs. This suggests that including NMVOC chemistry would likely have led to a larger estimate of the increase of tropospheric ozone, though not significantly so.

[8] All the simulations presented here are 40 year equilibrium simulations. In each case there was a spin-up period of at least 10 years to allow the chemistry to equilibrate. The major factors influencing atmospheric ozone are ODSs, tropospheric precursors including $\mathrm{CH}_{4}$, climate change (by which we mean all the temperature, circulation, and moisture changes due to increases in long-lived GHGs), and $\mathrm{N}_{2} \mathrm{O}$. To investigate these factors individually and in selected combinations, the simulations summarized in Table 1 were performed with certain combinations of PD and PI forcings in the chemistry and radiation components of the model, designed so that their differences reveal contributions to twentieth century changes in ozone from these forcing changes. The PD run has all boundary conditions set to present-day values, while the PI run has everything set to preindustrial conditions. The other simulations are generally set up so that subtracting their ozone distribution from that of PD gives the effect of interest. Thus, unless otherwise indicated, the effect presented corresponds to PD values for the remaining boundary conditions. Except for the full PI
Table 1. A Summary of the Simulations ${ }^{\mathrm{a}}$

\begin{tabular}{lccccc}
\hline Name & $\begin{array}{c}\text { GHGs, } \\
\text { SSTs }\end{array}$ & ODSs & $\mathrm{N}_{2} \mathrm{O}$ & $\mathrm{CH}_{4}$ & $\begin{array}{c}\mathrm{CO}, \\
\mathrm{NO}_{\mathrm{x}}\end{array}$ \\
\hline PD & 2000 & 2000 & 2000 & 2000 & 2000 \\
PI & 1880 & 1880 & 1880 & 1880 & 1880 \\
CHEM & 2000 & 1880 & 1880 & 1880 & 1880 \\
ODS & 2000 & 1880 & 2000 & 2000 & 2000 \\
PRE & 2000 & 2000 & 2000 & 1880 & 1880 \\
PREODS & 2000 & 1880 & 2000 & 1880 & 1880 \\
\hline
\end{tabular}

"The "GHGs" column indicates the year of the IPCC AR5 database used for the concentration of long-lived trace gases $\left(\mathrm{CO}_{2}, \mathrm{CH}_{4}, \mathrm{CFC}-11\right.$, CFC12 , and $\mathrm{N}_{2} \mathrm{O}$ ) used in the radiation, while the remaining columns indicate the year used for chemistry in the model but not radiation.

simulation, when chemical boundary conditions are set to PI values their greenhouse gas effect remains at the PD level so that, aside from unavoidable changes in ozone and water vapor effects, the GHG forcing of the simulations is the same as the PD simulation. This allows the dynamical and chemical effects to be separated as cleanly as possible.

[9] Monthly climatological sea surface temperatures (SSTs) and sea ice from the Hadley Centre [Rayner et al., 2003] were used for the period 1990-2009 for PD and 1870-1889 for PI conditions. Long-lived GHGs and chemical species representative of the year 2000 and 1880 were used for the PD and PI runs, respectively, based on the Intergovernmental Panel on Climate Change (IPCC) AR5 historical scenario [Meinshausen et al., 2011], as were emissions of $\mathrm{CO}$ and $\mathrm{NO}_{\mathrm{x}}$ from transportation, industrial sources, and biomass burning [Lamarque et al., 2010]. CO from soils and oceans and an additional $250 \mathrm{Tg} \mathrm{CO} / \mathrm{yr}$ to account for $\mathrm{CO}$ from isoprene oxidation were included for all scenarios. For PD emissions of $\mathrm{NO}_{\mathrm{x}}$ from soils, monthly averages from the Reanalysis of the Tropospheric chemical composition over the past 40 years (RETRO) project [Schultz et al., 2007] were used, while PI soil $\mathrm{NO}_{\mathrm{x}}$ emissions were derived by subtracting the IPCC AR5 year 2000 anthropogenic soil $\mathrm{NO}_{\mathrm{x}}$ emissions from the RETRO fields, resulting in estimates of 9.3 and $8.7 \mathrm{Tg} \mathrm{N} /$ year for PD and PI conditions, respectively. Emissions of lightning from $\mathrm{NO}_{\mathrm{x}}$ were parameterized from the model convective updraft mass flux based on Allen and Pickering [2002], scaled to provide 4 Tg N/year for PD conditions.

\section{Ozone Changes Since Preindustrial Times}

[10] Figure 1a shows the seasonal cycle of the zonally averaged total simulated column ozone change from preindustrial times, PD-PI. The Southern Hemisphere experiences column ozone decrease, especially in the Antarctic spring, as expected. There is, however, an increase in total column ozone over most of the Northern Hemisphere, especially at high latitudes in summer. Clearly, ODS-induced ozone destruction does not dominate the entire PD-PI column ozone change in these simulations as it has in the last 40 years [ $W M O, 2011]$. In fact, Table 2, which gives the column ozone changes separated into stratospheric and tropospheric components, shows near cancelation of the stratospheric decrease and tropospheric increase in the global average total column, giving a net change of only -1.8 DU. Note that the PI to PD increase in the global average tropospheric column of $8.1 \mathrm{DU}$ is equivalent to $88 \mathrm{Tg} \mathrm{O} 3$, which is quite close to the multimodel mean increase in tropospheric ozone between 1850 and 2000 found in ACCMIP of 
(a) Total Change (PD-PI)

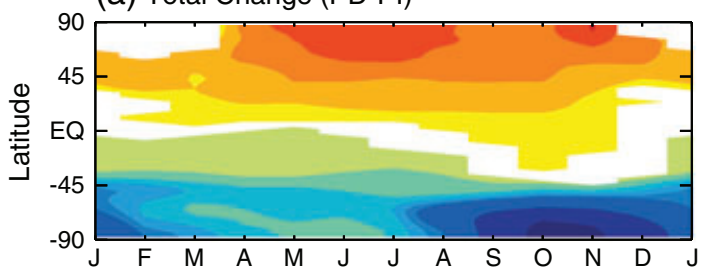

(c) Precursor Effect (PD-PRE)

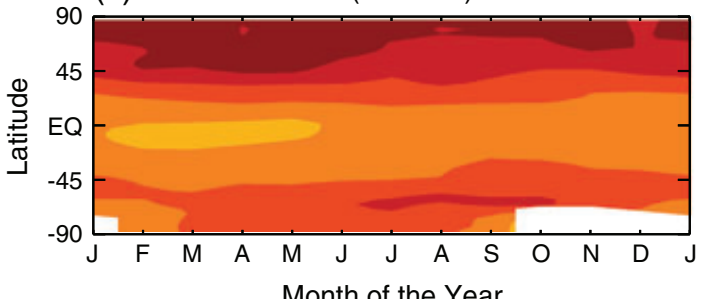

(b) ODS Effect (PD-ODS)

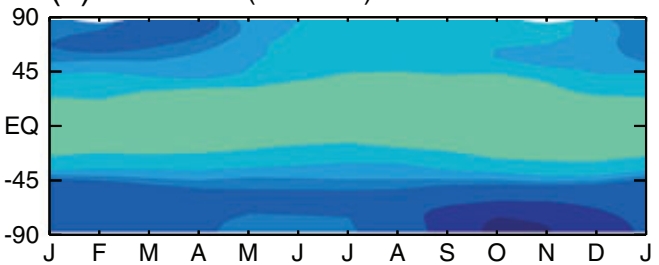

(d) Climate Effect (CHEM-PI)

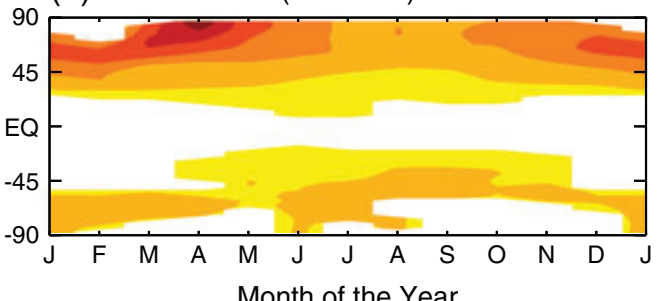

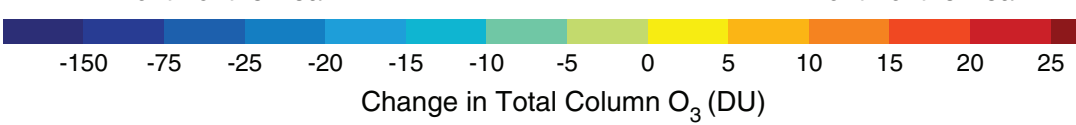

Figure 1. The average seasonal cycle of total column ozone change for (a) PD-PI, (b) PD-ODS, (c) PD-PRE, and (d) CHEM-PI. Only areas significant at the $95 \%$ level are colored.

$98 \mathrm{Tg}$ O3 [Young et al., 2013]. While the net change in column ozone is near zero in the global average, there are important hemispheric differences. In the northern midlatitudes the tropospheric increase $(+12.3 \mathrm{DU})$ dominates the stratospheric decrease $(-3.6 \mathrm{DU})$, while for southern midlatitudes a weaker increase of ozone in the troposphere $(+4.1 \mathrm{DU})$ is dominated by a large decrease in stratospheric ozone $(-14.7 \mathrm{DU})$. For the tropics we find that the changes in the stratosphere and troposphere largely cancel out. Using the set of simulations with different forcings, we investigate the origins of these differences below.

\subsection{The Effect of ODSs}

[11] Figure 1b shows the annual cycle of ODS effects on total column ozone derived as the difference between the PD and ODS run. Large decreases in column ozone are found throughout the year south of $45^{\circ} \mathrm{S}$, maximizing at greater than 100 DU over Antarctica during austral spring.
A qualitatively similar pattern of decrease is found for the Northern Hemisphere, though it is much smaller in magnitude. As shown in Table 2, ODSs are responsible for a small decrease in tropospheric ozone as well, with decreases of between $1 \mathrm{DU}$ and $3 \mathrm{DU}$ for the latitude bands analyzed. The extension of the ODS effect into the troposphere can be seen in Figure 2a, which presents the zonal and annual average percentage change in ozone due to ODSs. The effects of ODS-driven ozone depletion extend down to the surface, particularly over the southern high latitudes. These results are complementary to the findings of Zeng et al. [2010], who showed the effects of stratospheric ozone recovery increasing ozone throughout the extratropical troposphere, particularly in the Southern Hemisphere.

\subsection{The Effect of Precursors $\left(\mathrm{CO}, \mathrm{NO}_{\mathrm{x}}\right.$, and $\left.\mathrm{CH}_{4}\right)$}

[12] The effect of increased precursor emissions is, unsurprisingly, a global increase in column ozone (Figure 1c),

Table 2. Total, Stratospheric, and Tropospheric Column Ozone Change Averages (DU) and 95\% Confidence Intervals in Various Latitude Bands for the Effects Considered ${ }^{\text {a }}$

\begin{tabular}{lrrrrr}
\hline & & $35^{\circ} \mathrm{S}-60^{\circ} \mathrm{S}$ & $25^{\circ} \mathrm{S}-25^{\circ} \mathrm{N}$ & $35^{\circ} \mathrm{N}-60^{\circ} \mathrm{N}$ & Global \\
\hline Total change & total & $-10.5 \pm 1.4$ & $1.0 \pm 0.3$ & $8.6 \pm 1.1$ & $-1.8 \pm 0.3$ \\
PD-PI & strat. & $-14.7 \pm 1.4$ & $-7.0 \pm 0.3$ & $-3.6 \pm 1.0$ & $-9.9 \pm 0.3$ \\
& trop. & $4.1 \pm 0.2$ & $7.9 \pm 0.1$ & $12.3 \pm 0.1$ & $8.1 \pm 0.1$ \\
ODS effect & total & $-23.0 \pm 1.3$ & $-7.9 \pm 0.3$ & $-13.5 \pm 1.3$ & $-15.3 \pm 0.4$ \\
PD-ODS & strat. & $-19.9 \pm 1.3$ & $-6.9 \pm 0.3$ & $-12.5 \pm 1.2$ & $-13.8 \pm 0.3$ \\
& trop. & $-3.1 \pm 0.2$ & $-1.0 \pm 0.1$ & $-1.1 \pm 0.2$ & $-1.6 \pm 0.1$ \\
precursor effect & total & $15.6 \pm 1.5$ & $12.0 \pm 0.3$ & $22.0 \pm 1.1$ & $15.8 \pm 0.4$ \\
PD-PRE & strat. & $8.0 \pm 1.3$ & $2.5 \pm 0.4$ & $9.0 \pm 1.1$ & $5.9 \pm 0.4$ \\
& trop. & $7.7 \pm 0.3$ & $9.5 \pm 0.1$ & $13.0 \pm 0.1$ & $9.9 \pm 0.1$ \\
climate effect & total & $3.9 \pm 1.4$ & $0.5 \pm 0.3$ & $7.6 \pm 1.0$ & $3.5 \pm 0.3$ \\
CHEM-PI & strat. & $4.1 \pm 1.3$ & $1.0 \pm 0.4$ & $7.2 \pm 1.0$ & $3.6 \pm 0.3$ \\
& trop. & $-0.2 \pm 0.1$ & $-0.5 \pm 0.1$ & $0.5 \pm 0.1$ & $-0.1 \pm 0.1$ \\
combined $\mathrm{N}_{2} \mathrm{O}$ & total & $-0.7 \pm 1.4$ & $-1.9 \pm 0.4$ & $2.5 \pm 1.0$ & $-0.4 \pm 0.3$ \\
and climate effect & strat & $-0.5 \pm 1.3$ & $-1.3 \pm 0.4$ & $2.1 \pm 0.9$ & $-0.2 \pm 0.3$ \\
PREODS-PI & trop & $-0.2 \pm 0.1$ & $-0.5 \pm 0.1$ & $0.4 \pm 0.1$ & $-0.2 \pm 0.1$ \\
\hline
\end{tabular}

${ }^{\text {a }}$ The tropopause is defined as the level where the lapse rate is $2 \mathrm{~K} / \mathrm{km}$. 
(a) ODS Effect (PD-ODS)

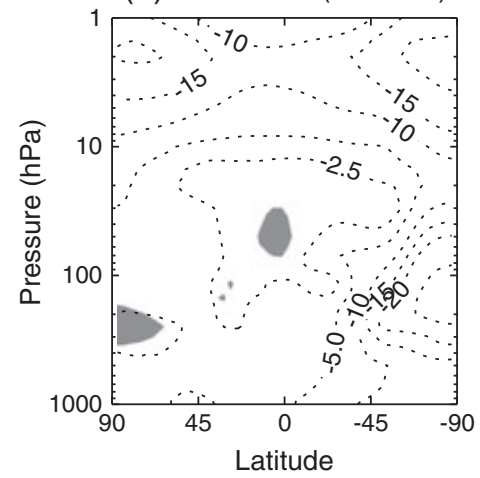

(b) Precursor Effect (PD-PRE)

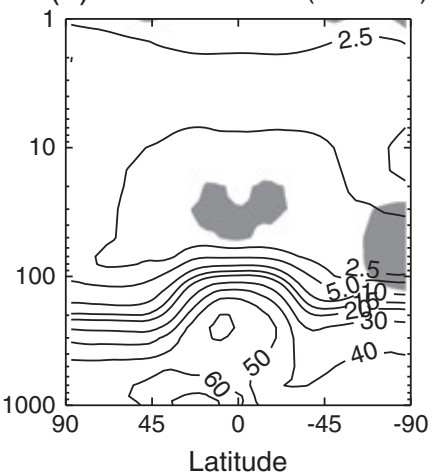

(c) Climate Effect (CHEM-PI)

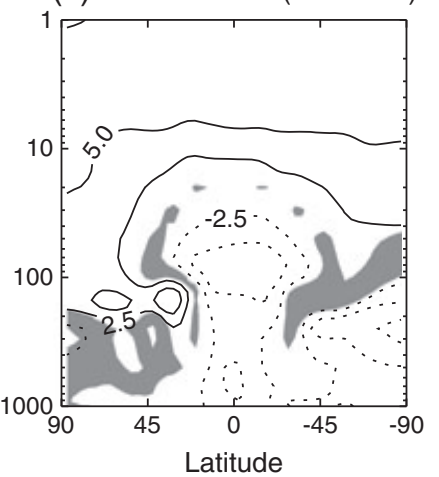

Figure 2. Annual and zonal average cross sections of percentage ozone change for (a) PD-ODS, (b) PD-PRE, and (c) CHEM-PI. Areas that are not significant at the $95 \%$ level are shaded.

driven largely by an increase in the troposphere. The increase is larger in the Northern Hemisphere because of the greater present-day precursor emissions there. In addition to the tropospheric increase, we find a 5.9 DU increase in the stratosphere that is much more evenly distributed between the northern and southern midlatitude bands, 9.0 and 8.0 DU, respectively. As can be seen in the cross section of PDPRE ozone changes (Figure 2b), much of the stratospheric increase occurs in the lowermost stratosphere, with approximately half of the extratropical stratospheric column increase occurring below $100 \mathrm{hPa}$ due to the increase in ozone production from methane oxidation [Randeniya et $a l ., 2002]$. There is also a widespread increase in ozone throughout much of the stratosphere, linked to moderation of chlorine-driven ozone destruction by the increase in methane. The increased methane in the PD run increases water vapor and, consequently, the destruction of ozone by $\mathrm{HO}_{\mathrm{x}}\left(\mathrm{OH}+\mathrm{HO}_{2}\right)$. The PD-PRE experiment shows increases in $\mathrm{HO}_{\mathrm{x}}$ of 15 to $20 \%$ in the stratosphere, though ozone decreases only above $1 \mathrm{hPa}$ (not shown) where ozone destruction by $\mathrm{HO}_{\mathrm{x}}$ chemistry becomes the dominant factor. As has been shown by Fleming et al. [2011] and Revell et al. [2012], among others, the dominant impact of increased methane on ozone is through increased sequestration of active chlorine through $\mathrm{Cl}+\mathrm{CH}_{4} \rightarrow \mathrm{HCl}+$ $\mathrm{CH}_{3}$, giving rise to a widespread increase in ozone throughout much of the stratosphere. Indeed, for the PD-PRE experiment we find reactive chlorine (the sum of $\mathrm{Cl}+\mathrm{Cl}_{2}+$ $\mathrm{ClO}+\mathrm{OClO}+\mathrm{Cl}_{2} \mathrm{O}_{2}+\mathrm{HOCl}+\mathrm{BrCl}$ ) decreases by 15 to $35 \%$ throughout the stratosphere. Note that the impact of $\mathrm{CH}_{4}$ on ozone is enhanced because the PD and PRE experiments were made under high chlorine loading conditions.

\subsection{The Effect of Climate Change}

[13] Figure 1d shows the climate change contribution to the column ozone change, defined as the CHEM-PI difference. The CHEM run (see Table 1) uses the same chemical boundary conditions as the PI run but uses PD values of GHGs in the radiation, PD SSTs, and PD sea ice. We find very little change in total column ozone in the tropics and an increase at higher latitudes, with a significantly stronger increase in the Northern Hemisphere. We can see from Table 2 that the effect of climate change on column ozone is predominantly stratospheric. The vertical cross section of the CHEM-PI change in ozone (Figure 2c) shows that ozone increases in the upper stratosphere, with the partial column of ozone above $20 \mathrm{hPa}$ increasing by $4 \mathrm{DU}$. We find that global, annual average temperatures decrease by between $2.5 \mathrm{~K}$ at $20 \mathrm{hPa}$ and $4 \mathrm{~K}$ at $1 \mathrm{hPa}$ (not shown) in the CHEM run compared to the PI run. The cooling is primarily driven by the increase in $\mathrm{CO}_{2}$ and changes the rate of gas phase reactions, producing a decrease in the rate of ozone loss by oxygen [Haigh and Pyle, 1982] and reactive nitrogen [Rosenfield and Douglass, 1998] catalytic cycles. The lower stratosphere shows a pattern of contrasting changes, with decreases at low latitudes and increases at higher latitudes, due to an acceleration of the residual circulation of the stratosphere [Butchart et al., 2006] reducing transport times of ozone-poor tropospheric air upward in the tropics and increasing poleward transport of ozone [Shepherd, 2008; Waugh et al., 2009]. The latter effect is much stronger in the Northern Hemisphere than in the Southern Hemisphere, explaining the larger increase in column ozone there.

\subsection{The Effect of $\mathrm{N}_{2} \mathrm{O}$}

[14] As discussed above, the effects of reactive nitrogen on stratospheric ozone are strongly modulated by changes in temperature. The dominant source of reactive nitrogen in the stratosphere is the breakdown of $\mathrm{N}_{2} \mathrm{O}$; thus, there is an important interplay between changes in $\mathrm{CO}_{2}$ and $\mathrm{N}_{2} \mathrm{O}$. The effects of climate change on ozone discussed in section 3.3, CHEM-PI, were derived keeping the tropospheric concentration of $\mathrm{N}_{2} \mathrm{O}$ constant at preindustrial levels and resulted in a decrease in stratospheric reactive nitrogen $\left(\mathrm{NO}_{\mathrm{y}}\right)$ concentrations of between 2.5 and $5 \%$ over the mid to upper stratosphere where nitrogen chemistry is the dominant ozone loss process. We have also assessed the combined effects of climate change and increased $\mathrm{N}_{2} \mathrm{O}$ through the difference of the simulations PREODS-PI. The tropospheric concentration of $\mathrm{N}_{2} \mathrm{O}$ was specified to increase by $14 \%$ between 1880 and 2000 , though we find an increase of only 3 to $7 \%$ in $\mathrm{NO}_{\mathrm{y}}$ through the mid to upper stratosphere due to the ameliorating effects of cooler stratospheric temperatures as well as a strengthened Brewer-Dobson circulation leaving less time for the photochemical breakdown of $\mathrm{N}_{2} \mathrm{O}$ [Plummer et al., 2010]. The global average stratospheric increase of 3.6 DU due to the climate change effect is eliminated when climate and $\mathrm{N}_{2} \mathrm{O}$ simultaneously change. This is largely due to reduction of the climate-induced ozone increase above $20 \mathrm{hPa}$ from $4 \mathrm{DU}$ to $1 \mathrm{DU}$. 


\subsection{Stratosphere-Troposphere Exchange}

[15] We calculate the flux of ozone from the stratosphere to the troposphere, the stratosphere-troposphere exchange (STE), as the residual required to balance the annual tropospheric ozone budget; the sum of photochemical production, photochemical destruction, and dry deposition. The PD experiment has a calculated STE of $544 \mathrm{Tg}$ O3/year, close to the observation-based estimate of Olsen et al. [2001] of $550 \pm 140 \mathrm{Tg} \mathrm{O} 3 /$ year and within the range of modelbased estimates given in Stevenson et al. [2006] of $556 \pm$ $154 \mathrm{Tg} \mathrm{O} 3 /$ year. We find the total PD-PI change in STE is $-41 \pm 5 \mathrm{Tg} \mathrm{O} /$ year. Using the series of experiments described above, the decrease in STE is composed of increases due to climate change $(+21 \pm 3 \mathrm{Tg} / \mathrm{yr})$ and precursor effects $(+31 \pm 8 \mathrm{Tg} / \mathrm{yr})$, with the increase in STE from precursors (PD-PRE) resulting from the increase in ozone in the lower stratosphere due to the increased $\mathrm{CH}_{4}$. These increases are offset by a large decrease in STE due to ODSs ( $-75 \pm 5 \mathrm{Tg}$ /year), with $85 \%$ of the decrease occurring in the Southern Hemisphere. The clearest signal of changes in STE on tropospheric ozone is found for the effect of ODSs, with the strong hemispheric asymmetry in the decrease in STE reflected in decreased tropospheric ozone.

\section{Discussion and Conclusions}

[16] Our analysis illustrates the complex interplay of ODSs, tropospheric precursors, $\mathrm{N}_{2} \mathrm{O}$, and climate change in effecting changes in the distribution of atmospheric ozone. While ODSs predominantly decrease stratospheric ozone, they also decrease tropospheric ozone by up to $3 \mathrm{DU}$ in the southern midlatitudes. Methane, which acts as a tropospheric precursor, also increases ozone significantly throughout the stratosphere. Climate change produces increased ozone in the upper stratosphere more or less equally around the globe, while producing a pattern in the lower stratosphere of decreased tropical and increased extratropical concentrations due to the acceleration of the stratospheric residual circulation, most strongly in the Northern Hemisphere. Including the climate-sensitive effects of the $\mathrm{N}_{2} \mathrm{O}$ increase since preindustrial times very nearly cancels the increase in globally averaged column ozone due to climate change with constant $\mathrm{N}_{2} \mathrm{O}$. Finally, including the projected increases in tropospheric ozone, which we calculate to be comparable to other current model-based estimates, we find net positive changes in total column ozone from preindustrial to present day over the Northern Hemisphere, relatively small changes over the tropics, and increasingly negative changes as one moves to higher latitudes in the southern extratropics.

[17] Our simulations suggest that the global average ODS-induced decrease in total column ozone since preindustrial times has been largely offset by tropospheric ozone increase and the effects of climate change. Gauss et al. [2006], who analyzed the combined effects of tropospheric and stratospheric changes on column ozone from preindustrial to present day, included one model, the NCAR MACCM, with both a chemically interactive stratosphere and the effects of climate change. This model projected a decrease in stratospheric ozone of 12.7 DU and an increase of 9.4 DU in the troposphere, yielding a net change in column ozone of $-3.3 \mathrm{DU}$, similar in nature and magnitude to our estimate of $-1.8 \mathrm{DU}$.
[18] Our finding that tropospheric ozone changes cannot be attributed entirely to tropospheric forcings, nor stratospheric changes to stratospheric forcings, is consistent with the finding of Shindell et al. [2013] concerning the impact of ODS and tropospheric precursor changes on ozone radiative forcing. In Shindell et al. [2013] the relative magnitude of the tropospheric and stratospheric effects is larger than found here since tropospheric ozone changes generally have a larger impact on radiative forcing than do stratospheric changes.

[19] These results illustrate the complex ways in which anthropogenic influences have affected the Earth's ozone distribution, including well-established harm from significant ozone depletion at high latitudes of the Southern Hemisphere and increases in ground level ozone that are particularly acute in industrialized areas. Models capable of simulating all these processes interactively are necessary to understand anthropogenic changes in ozone and allow for estimation of the impacts on human health and ecosystems of the changes in surface UV and surface ozone. The complexity of the interactions also underlines the need for continued comprehensive observations of atmospheric composition to ensure that our understanding of atmospheric change is correct.

[20] Acknowledgments. This work was funded by the Canadian Foundation for Climate and Atmospheric Sciences (CFCAS) through the C-SPARC network and the Canadian Space Agency through the CMAM20 project. The authors thank the two anonymous reviewers for comments that improved the paper.

[21] The Editor thanks two anonymous reviewers for their assistance in evaluating this paper.

\section{References}

Allen, D. J., and K. E. Pickering (2002), Evaluation of lightning flash rate parameterizations for use in a global chemical transport model, J. Geophys. Res., 107(D23), 4711, doi:10.1029/2002JD002066.

Brühl, C., and P. J. Crutzen (1989), On the disproportionate role of tropospheric ozone as a filter against solar UV-B radiation, Geophys. Res. Lett., 16, 703-706.

Butchart, N., et al. (2006), Simulations of anthropogenic change in the strength of the Brewer-Dobson circulation, Clim. Dyn., 27, 727-741, doi:10.1007/s00382-006-0162-4.

Cionni, I., V. Eyring, J. F. Lamarque, W. J. Randel, D. S. Stevenson, F. Wu, G. E. Bodeker, T. G. Shepherd, D. T. Shindell, and D. W. Waugh (2011), Ozone database in support of CMIP5 simulations: Results and corresponding radiative forcing, Atmos. Chem. Phys., 11, 11,267-11,292, doi:10.5194/acp-11-11267-2011.

Dvortsov, V. L., and S. Solomon (2001), Response of the stratospheric temperatures and ozone to past and future increases in stratospheric humidity, J. Geophys. Res., 106, 7505-7514.

Eyring, V., et al. (2005), A strategy for process-oriented validation of coupled chemistry-climate models, Bull. Am. Meteorol. Soc., 86, 1117-1133, doi:10.1175/BAMS-86-8-1117.

Fleming, E. L., C. H. Jackman, R. S. Stolarski, and A. R. Douglass (2011), A model study of the impact of source gas changes on the stratosphere for 1850-2100, Atmos. Chem. Phys., 11, 8515-8541, doi:10.5194/acp11-8515-2011.

Gauss, M., et al. (2006), Radiative forcing since preindustrial times due to ozone change in the troposphere and the lower stratosphere, Atmos. Chem. Phys., 6, 575-599.

Gregg, J. W., C. G. Jones, and T. E. Dawson (2003), Urbanization effects on tree growth in the vicinity of New York City, Nature, 424, 183-187.

Haigh, J. D., and J. A. Pyle (1982), Ozone perturbation experiments in a two-dimensional circulation model, Q. J. R. Meteorol. Soc., 108, $551-574$

Jerret, M., R. T. Burnett, C. A. Pope III, K. Ito, G. Thurston, D. Krewski, Y. Shi, E. Calle, and M. Thun (2009), Long-term ozone exposure and mortality, N. Engl. J. Med., 360, 1085-1095.

Jonsson, A. I., J. de Grandpré, V. I. Fomichev, J. C. McConnell, and S. R. Beagley (2004), Doubled $\mathrm{CO}_{2}$-induced cooling in the middle atmosphere: Photochemical analysis of the ozone radiative feedback, J. Geophys. Res., 109, D24103, doi:10.1029/2004JD005093. 
Lamarque, J.-F., P. G. Hess, L. K. Emmons, L. E. Buja, W. M. Washington, and C. Granier (2005), Tropospheric ozone evolution between 1890 and 1990, J. Geophys. Res., 110, D08304, doi:10.1029/2004JD005537.

Lamarque, J.-F., et al. (2010), Historical (1850-2000) gridded anthropogenic and biomass burning emissions of reactive gases and aerosols: Methodology and application, Atmos. Chem. Phys., 10, 7017-7039, doi:10.5194/acp-10-7017-2010.

Marenco, A., H. Gouget, P. Nédélec, J.-P. Pagés, and F. Karcher (1994), Evidence of a long-term increase in tropospheric ozone from Pic du Midi data series: Consequences: Positive radiative forcing, J. Geophys. Res., 99, 16,617-16,632.

Meinshausen, M., et al. (2011), The RCP greenhouse gas concentrations and their extensions from 1765 to 2300, Clim. Change, 109, 213-241, doi:10.1007/s10584-011-0156-z.

Olsen, S. C., C. A. McLinden, and M. J. Prather (2001), Stratospheric $\mathrm{N}_{2} \mathrm{O}-$ $\mathrm{NO}_{\text {y }}$ system: Testing uncertainties in a three-dimensional framework, J. Geophys. Res., 106, 28,771-28,784.

Oltmans, S. J., et al. (2013), Recent tropospheric ozone changes-A pattern dominated by slow or no growth, Atmos. Environ., 67, 331-351.

Parrish, D. D., et al. (2012), Long-term changes in lower tropospheric baseline ozone concentrations at northern mid-latitudes, Atmos. Chem. Phys., 12, 11,485-11,504, doi:10.5194/acp-12-11485-2012.

Plummer, D. A., J. F. Scinocca, T. G. Shepherd, M. C. Reader, and A. I. Jonsson (2010), Quantifying the contributions to stratospheric ozone changes from ozone depleting substances and greenhouse gases, Atmos. Chem. Phys., 10, 8803-8820, doi:10.5194/acp-10-8803-2010.

Randeniya, L. K., P. F. Vohralik, and I. C. Plumb (2002), Stratospheric ozone depletion at northern mid latitudes in the $21^{\text {st }}$ century: The importance of future concentrations of greenhouse gases nitrous oxide and methane, Geophys. Res. Lett., 29(4), 1051, doi:10.1029/2001GL014295.

Rayner, N. A., D. E. Parker, E. B. Horton, C. K. Folland, L. V. Alexander, D. P. Rowell, E. C. Kent, and A. Kaplan (2003), Global analyses of sea surface temperature, sea ice, and night marine air temperature since the late nineteenth century, J. Geophys. Res., 108 (D14), 4407, doi:10.1029/2002JD002670.

Revell, L. E., G. E. Bodeker, P. E. Huck, B. E. Williamson, and E. Rozanov (2012), The sensitivity of stratospheric ozone changes through the $21 \mathrm{st}$ century to $\mathrm{N}_{2} \mathrm{O}$ and $\mathrm{CH}_{4}$, Atmos. Chem. Phys., 12, 11,309-11,317, doi:10.5194/acp-12-11309-2012.

Rosenfield, J. E., and A. R. Douglass (1998), Doubled $\mathrm{CO}_{2}$ effects on $\mathrm{NO}_{\mathrm{y}}$ in a coupled 2D model, Geophys. Res. Lett., 25, 4381-4384.
Schultz, M. G., and S. Rast (Eds.) (2007), Emission datasets and methodologies for estimating emissions, RETRO Rep. D1-6, available at http:// retro.enes.org (last accessed April 10, 2013).

Shepherd, T. G. (2008), Dynamics, stratospheric ozone, and climate change, Atmos. Ocean, 46, 117-138.

Shindell, D. T., G. Faluvegi, D. M. Koch, G. A. Schmidt, N. Unger, and S. E. Bauer (2009), Improved attribution of climate forcing to emissions, Science, 326, 716-718, doi:10.1126/science.1174760.

Shindell, D. T., G. Faluvegi, L. Nazarenko, K. Bowman, J.-F. Lamarque, A. Voulgarakis, G. A. Schmidt, O. Pechony, and R. Ruedy (2013), Attribution of historical ozone forcing to anthropogenic emissions, Nat. Clim. Change, 3, 567-570, doi:10.1038/nclimate1835.

SPARC CCMVal (2010), SPARC report on the evaluation of chemistryclimate models, V. Eyring, T. G. Shepherd, D. W. Waugh (Eds.), SPARC Rep. 5, WCRP-132, WMO/TD-No. 1526.

Stevenson, D. S., et al. (2006), Multimodel ensemble simulations of present-day and near-future tropospheric ozone, J. Geophys. Res., 111, D08301, doi:10.1029/2005JD006338.

Stevenson, D. S., et al. (2013), Tropospheric ozone changes, radiative forcing and attribution to emissions in the Atmospheric Chemistry and Climate Model Intercomparison Project (ACCMIP), Atmos. Chem. Phys. 13, 3063-3085, doi:10.5194/acp-13-3063-2013.

Volz, A., and D. Kley (1988), Evaluation of the Montsouris series of ozone measurements made in the nineteenth century, Nature, 332, 240-242, doi: $10.1038 / 332240 \mathrm{a} 0$.

Waugh, D. W., L. Oman, S. R. Kawa, R. S. Stolarski, S. Pawson, A. R. Douglass, P. A. Newman, and J. E. Nielsen (2009), Impacts of climate change on stratospheric ozone recovery, Geophys. Res. Lett., 36, L03805, doi:10.1029/2008GL036223.

WMO (World Meteorological Organization) (2011), Scientific assessment of ozone depletion: 2010, Rep. 52, Global Ozone Res. and Monit. Proj., 516 pp., Geneva, Switz.

Young, P. J., et al. (2013), Pre-industrial to end 21st century projections of tropospheric ozone from the Atmospheric Chemistry and Climate Model Intercomparison Project (ACCMIP), Atmos. Chem. Phys., 13, 2063-2090.

Zeng, G., O. Morgenstern, P. Braesicke, and J. A. Pyle (2010), Impact of stratospheric ozone recovery on tropospheric ozone and its budget, Geophys. Res. Lett., 37, L09805, doi:10.1029/2010GL042812. 